\title{
Isolation, identification and antimicrobial activities of Lactic Acid Bacteria from fruits of wild plants in Tambrauw Forest, West Papua, Indonesia
}

\author{
ACHMAD DINOTO', ${ }^{1, \bullet}$, A'LIYATUR ROSYIDAH ${ }^{1}$, ANGGI RIA PUSPITA SARI SUSILO² ${ }^{2}$, HEDDY JULISTIONO ${ }^{1}$ \\ ${ }^{1}$ Microbiology Division, Research Center for Biology, Indonesian Institute of Sciences. Jl. Raya Jakarta-Bogor Km. 46, Cibinong, Bogor 16911, West \\ Java, Indonesia. Tel./fax.: +62-21-8765066/87907612, •email: achmaddinoto@yahoo.com \\ ${ }^{2}$ Program Study of Pharmacy, National Institute of Science and Technology. Jl. Moh. Kahfi II, Srengseng Sawah, Jakarta 12630 Indonesia
}

Manuscript received: 14 April 2020. Revision accepted: 29 June 2020.

\begin{abstract}
Dinoto A, Rosyidah A, Susilo ARPS, Julistiono H. 2020. Isolation, identification and antimicrobial activities of Lactic Acid Bacteria from fruits of wild plants in Tambrauw Forest, West Papua, Indonesia. Biodiversitas 21: 3391-3397. Presence of culturable lactic acid bacteria (LAB) in fruits of wild plants and their antimicrobial activities has not been widely reported. The purposes of this study were to isolate LAB from the fruits of wild plants found in the Tambrauw forest area, West Papua Indonesia, and to evaluate their antimicrobial activities. Isolation of LAB from fruit was conducted using MRS medium supplemented with $1 \% \mathrm{CaCO}_{3}$. Isolates of $\mathrm{LAB}$ were identified based on 16S rRNA gene using BLAST analysis. Antimicrobial assays were carried out by determining the minimum inhibitory concentration (MIC) based on thiazolyl blue tetrazolium blue (MTT) using indicator microorganisms Escherichia coli, Staphylococcus aureus, and Mycobacterium smegmatis. The results showed that total of fourteen isolates of LAB with different characteristics was successfully isolated from 8 of 14 collected wild plants. Based on 16S rRNA sequences, isolates had closest relationships with Lactococcus lactis, Lactococcus garvieae, Weissella confusa, Weissella oryzae, and Enterococcus faecalis with the similarity of $99 \%$. All 16S rRNA nucleotides of these strains have been deposited in the GenBank. Assays for antimicrobial activities were demonstrated by the highest inhibition of supernatant of Lac. lactis HM 1.1 from fruit plant Donax canniformis and W. confusa H14.2 from fruit plant Capparis sp. against E. coli, S. aureus, and M. smegmatis even though the MIC values of those strains were lower than that of bacterial strain from the commercial probiotic product. This study showed that wild fruit from Tambrauw forest harbor beneficial lactic acid bacteria that could be important for health of animals and humans as well. In addition, this study provided basic information on indigenous LAB for promoting further development of medicinal antibacterial compounds.
\end{abstract}

Keywords: Antimicrobial activity, Escherichia coli, lactic acid bacteria, Mycobacterium smegmatis, Staphylococcus aureus, wild fruits

Abbreviations: LAB: lactic acid bacteria; MIC: minimum inhibitory concentration; MTT: thiazolyl blue tetrazolium blue

\section{INTRODUCTION}

Lactic acid bacteria are a group consisting of microbial strains that ferment sugar predominantly to lactic acid, Gram positive, typically non- sporulating rod or coccus shaped (Ray et al. 2014; Ali 2010). The presences of LABs were reported in many plant-based fermented products of vegetables and also in flower and fruits (Karyawati et al. 2018; Mangunwardoyo et al. 2016; Sulistiani et al. 2014; Swain et al. 2014). LAB formed association with both animal and plant niches and play an important role in the production of fermented food (Makarova et al. 2006). The $\mathrm{LAB}$ originated from forests that have good potential to be explored. The application of $\mathrm{LAB}$ as biocontrol and probiotic agents are examples of its potential (Hwanhlem et al. 2014). Probiotics are dietary supplements consisting of living bacteria with various health benefits (Gowri et al 2016). Nonetheless, probiotics could be also beneficial for animals.

LABs are found in wild animals as well as gorillas (Tsuchida et al. 2014). The presence of LAB in the natural environment could be an object of study on ecology considering the interaction between LAB-plants and animals. This speculation as proposed by Choi et al. (Choi et al. 2016) showed that LAB in Citrus medica was able to attract wild nematodes (Caenorhabditis elegans) due to the diacetyl produced from fermentation by LAB which was detected by diacetyl odor receptor (ODR-10). Whereas other studies of Lactobacillus casei showed that $C$. elegans proved to be useful as probiotics that protected nematodes from oxidative stress (Kamaladevi et al. 2013) and improved the phase II detoxification system caused by in vivo malathion pesticides (Kamaladevi et al. 2016).

As typical rain forest, Tambrauw forest area located in West Papua, Indonesia is an area with the most diverse organisms (Robiansyah 2018). Microbial diversity in this area especially for LAB is less observed. In addition, although fruit is one source of feeds, the impact of the presence of LAB on fruits on animals consuming the wild fruit has not been studied. Considering the reports on the presence of LAB on fruits ( $\mathrm{Yu}$ et al. 2017; Chen et al. 2010; Leong et al. 2014), the effects of LAB on animals that consume the aforementioned fruits are possible and lead to the core idea of LAB roles in biodiversity studies of 
forest ecosystems. The study on presence of LAB on wild fruits in the Tambrauw forest is expected to be preliminary data on the study of LAB-animal-plant interaction in the forest ecosystem. In addition, the finding of LAB which has probiotic properties such as antimicrobial activity against pathogens was expected to be applied on animals and humans. By collecting the indigenous LAB and investigating the potential properties of pathogens inhibition may lead to the further development of medicinal antibacterial compounds.

The purposes of this study were to isolate lactic acid bacteria (LAB) from the fruits of wild plants found in the Tambrauw forest area, West Papua Indonesia, and to evaluate their antimicrobial activities. Several antimicrobial activities of selected LAB isolated from wild fruits in Tabrauw forest were investigated against three indicator microbes including Escherichia coli (Gram-negative), $S$. aureus (Gram-positive) and M. smegmatis (Mycobacterium spp. model). E. coli and $S$. aureus are enteropathogenic bacteria and able to infect wild animals (de Godoy et al. 2016; Iovine et al. 2015). Mycobacterium spp. could promote infection in the gastrointestinal tract (Sangari et al 2001) and be found in the oropharynx of some wild mammals (Albertti et al. 2014).

\section{MATERIALS AND METHODS}

\section{Microorganisms used in this study}

Target microbes used as pathogen models were Escherichia coli InaCC B5, Staphylococcus aureus InaCC B4, and Mycobacterium smegmatis NBRC 3082 which are obtained from Indonesian Culture Collection (InaCC). The three target microbes were inoculated on nutrient broth (Himedia). Incubation was performed at room temperature on shaker (100 rpm) for 24 hours (E. coli and S. aureus) or for 72 hours (M. smegmatis) on nutrient agar (Himedia). Bacterial strain isolated from the commercial probiotic product was used as reference microorganisms in antimicrobial assays, in which Lactobacillus casei is recognized from the product label. This strain from commercial probiotic product was maintained on de Man Rogosa and Sharpe broth (MRS Broth-Oxoid).

\section{Sample collection and bacterial isolation}

Sampling was conducted in Tambrauw forest area, West Papua, Indonesia on April 2016. Plants specimens were identified and deposited in Herbarium Bogoriense (BO), Indonesian Institute of Sciences, Bogor, Indonesia. Fruit samples were picked from the tree and cut to small pieces $(0.4 \mathrm{~cm} \times 0.4 \mathrm{~cm} \times 0.4 \mathrm{~cm})$ with a $70 \%$ ethanolsterilized knife. The pieces of fruits were swiftly placed on $5 \mathrm{ml}$ of MRS agar (Oxoid) in a $15 \mathrm{ml}$ "corning" tube with or without the addition of $7 \mathrm{ml}$ of sterilized cooking oil. The addition of oil on the surface of the medium was performed to reduce the amount of air oxygen that could dissolve in the MRS agar media thus inhibiting the growth of LAB in the field. Media containing pieces of fruits were left for about 10 days in the field before further isolation in the laboratory. LAB isolation was carried out by serial dilution (up to $10^{8}$ dilution series) with sterilized $0.85 \%$ $\mathrm{NaCl}$ solution and poured onto MRS agar (Oxoid) containing $1 \% \mathrm{CaCO}_{3}$ in petri dish. Incubation was conducted at $37^{0} \mathrm{C}$ for 24 hours. The formation of LAB colonies was indicated by a clear zone around the colony on MRS agar containing $\mathrm{CaCO}_{3}$. Selected colonies were transferred to a new medium for purification and the purified isolates were then preserved both in slanted agar and in the glycerol medium at $-80^{\circ} \mathrm{C}$ deep freezer.

\section{DNA extraction}

Genomic DNA extraction of each isolate was performed following method of phenol treatment (Saito and Miura 1963) with some modifications. Purified LAB colonies ( 2 days) were put in microtube containing $500 \mu \mathrm{L}$ TE $1 \mathrm{x}$, subsequently homogenized and then centrifuged at $9,000 x g, 4^{\circ} \mathrm{C}$, for $5 \mathrm{~min}$ to obtain pellet. Pellet was added with $50 \mu \mathrm{L}$ TE $1 \mathrm{x}$ and $300 \mu \mathrm{L}$ buffer extraction, homogenized using a vortex, and added with $150 \mu \mathrm{L} 3 \mathrm{M}$ sodium acetate $\mathrm{pH}$ 5.2. After incubation at room temperature for $10 \mathrm{~min}$, the mixture was centrifuged at $9,000 \times \mathrm{g}, 4^{\circ} \mathrm{C}$, for $5 \mathrm{~min}$. Supernatant was then added with isopropanol $(1: 1, \mathrm{v} / \mathrm{v})$ and centrifuged at $9,000 \mathrm{xg}, 4^{\circ} \mathrm{C}$, for 5 min. Pellet was resuspended with $500 \mu \mathrm{L}$ of ethanol $70 \%$ and centrifuged again at $9,000 \mathrm{xg}, 4^{\circ} \mathrm{C}$, for $5 \mathrm{~min}$. Washed pellet in microtube was then dried, resuspended with $50 \mu \mathrm{L}$ $\mathrm{TE} 1 \mathrm{x}$, and stored in the freezer at $-20^{\circ} \mathrm{C}$.

\section{PCR amplification and phylogeny analysis}

The universal $16 \mathrm{~S}$ rDNA primers, forward primer $27 \mathrm{~F}$ (5'-AGAGTTTGATCCTGGCTCAG-3') and reverse primer 1492R (5'-ACCTTGTTACGACTT-3') (Lane et al. 1985) prepared by Integrated DNA Technologies were used in PCR amplification. The PCR amplification was carried out in a reaction mixture containing $1 \mu \mathrm{L}$ genomic DNA as template $(100 \mu \mathrm{g} / \mathrm{ul}), 1 \mu \mathrm{L}$ forward $(10 \mathrm{pM}), 1 \mu \mathrm{L}$ reverse primer (10 pM), 0.5 $\mu \mathrm{L}$ DMSO (Sigma), $12.5 \mu \mathrm{L}$ GoTaq mix (Promega), and nuclease-free water (Promega) up to the final volume of $50 \mu \mathrm{L}$ reaction mixture. PCR amplification was performed using Thermal Cycler (Takara) with the following cycles: $90 \mathrm{sec}$ initial denaturation at $94^{\circ} \mathrm{C} ; 30 \mathrm{sec}$ denaturation at $95^{\circ} \mathrm{C} ; 30 \mathrm{sec}$ primer annealing at $55^{\circ} \mathrm{C}$; $90 \mathrm{sec}$ elongation at $72^{\circ} \mathrm{C}$; and a final extension of $10 \mathrm{~min}$ at $72^{\circ} \mathrm{C}$. PCR cycle used was 35 cycles., Electrophoresis of PCR amplified products was conducted on $1.2 \%(\mathrm{w} / \mathrm{v})$ low-EEO agarose gel in $1 \mathrm{X}$ TBE buffer (45 mM Tris-borate, $\mathrm{pH} 8.3$, and $1 \mathrm{mM}$ Na 2 EDTA) at $100 \mathrm{~V}$ for $20 \mathrm{~min}$. The gel was stained with ethidium bromide $(0.5 \mu \mathrm{g} / \mathrm{mL})$ and visualized under exposure of UV light. The amplified 16S rRNA gene of isolates was then analysis for sequencing by Macrogen Korea. The $16 \mathrm{~S}$ rRNA sequences were subsequently aligned with the multiple alignment method using Clustal X version 2.0 (Thompson et al. 1997) and BLAST was performed with the database available on NCBI (http: //www.ncbi.nlm.nih.gov) on April 8, 2019. The phylogenetic trees were constructed using Clustal $\mathrm{X}$ version 2.0 software with neighbor-joining method of 1000 bootstraps (Saitou and Nei 1987). 


\section{Screening of LAB antimicrobial activities}

In the initial screening for antimicrobial activity of LAB, the "disk diffusion" method was applied (Wanger 2007). Supernatants from the 48-hour LAB were prepared by microcentrifugation (miniSprin, Eppendorf) at 10,000 rpm for $10 \mathrm{~min}$ ). Centrifugation was performed aseptically and the cell-free supernatant was obtained. After incubation, the target microbial suspension was taken and diluted 10 times. About $100 \mu \mathrm{l}$ of sample was taken and poured over the NA medium; then on it was placed a paper disc that previously dipped in the LAB supernatant. Depending on the cultures, after incubation for 24 hours $(E$. coli and S. aureus) and 72 hours (M. smegmatis), the formation of clear zones was measured using a ruler. The measurement was performed in duplicate.

\section{The assay of minimum inhibition concentration}

Antimicrobial activities of cell culture supernatants were measured by determining minimum inhibition concentration (MIC) using MTT (thiazolyl blue tetrazolium blue) (El Baz and Shetaia 2005; Moodley et al. 2014). MIC assay was performed on 96-well microplate at room temperature. The test of MIC of supernatant against target microbes was conducted by inoculating culture $(1 / 100$ initial density) on NB medium as much as $100 \mu$ with a series of 40, 20, 10, 5, and 0\% supernatant concentrations. Samples were shaken at $100 \mathrm{rpm}$ for 24 hours or 72 hours. After incubation, each suspension was added with $10 \mu \mathrm{l}$ of MTT solution $(5 \mathrm{mg} / \mathrm{mL})$ and incubated for 2 hours. After incubation, cell suspension was added with $11 \mu \mathrm{l}$ of propanol containing $0,04 \mathrm{M} \mathrm{HCl}$, and incubated again for 2 hours; formazan formed from the reduction of MTT by enzymes in the cell was then read with a microplate reader (Bio-rad iMark) at a wavelength of $595 \mathrm{~nm}$. MIC was determined at the same absorbance value of the NB media value, the value at the time of the absence formazan due to no detection of the activity by the reducing enzyme.

\section{The effect of high temperature on antimicrobial activity}

Supernatants predicted containing bacteriocin were tested for their stability during heating in accordance with (Noonpakdee et al. (2002) and Bungenstock et al. (2020). The supernatant was heated at $80^{\circ} \mathrm{C}$ for 15 minutes to investigate the presence of supernatant active ingredients that are sensitive to heat. The MIC of heated supernatant was tested. The antimicrobial activity of the isolated LAB was compared to the antimicrobial activity of commercial LAB which was isolated from probiotic products containing $L b$. casei. The treatment was performed with three replications.

\section{RESULTS AND DISCUSSION}

\section{Lactic acid bacteria in fruits of wild plants}

Total of fourteen samples of fruit obtained as source of LAB were successfully been identified as Donax canniformis (G.Forst.) K.Schum., Dysoxylum parasiticum (Osbeck) Kosterm., Tabernaemontana aurantiaca Gaudich., Tetrastigma papillosum Planch., Ficus arfakensis King., Pinanga sp., Lasianthus sp., Dracaena angustifolia (Medik.) Roxb., Syzygium sp., Myristica subalulata Miq., Helicia moluccana (R, Br) Blume., Galearia celebica Koord., Cordyline sp., and Capparis sp.; representing fourteen different families (Table 1.) As many fourteen isolates were obtained from both media containing oil (4 isolates) and without oil (10 isolates).

In this study, LAB was actually found in all collected fruits and could grow in liquid medium (MRS broth) during the first step of isolation in the field of Tambrauw forest. Unfortunately, when cell suspensions arrived at the laboratory after 10 days of incubation, not all of them could grow well on solid media (MRS Agar). Probably, it was related to the sensitivity to oxygen or other unidentified factors. In addition, the length of time between initial isolation in the field and in the laboratory contributed to the failure of the isolation. We observed that LAB isolates were not obtained from fruits of Dysoxylum parasiticum (Osbeck) Kosterm. (No. 2), Ficus arfakensis King. (No. 5), Pinanga sp. (No. 6), and Dracaena angustifolia (Medix) Roxb. (No. 8) (Table 1).

LAB identification was performed by amplifying and sequencing the universal region of $16 \mathrm{~S}$ rRNA gene. PCR amplification of all isolates was successfully conducted based on observation on electrophoresis gel at about 1500 bp. As result, the contig sequences obtained from all isolates were about $1349-1370$ in base pairs length, and they were sufficient to compare with the collection of rRNA sequences of the NCBI GenBank. BLAST analysis demonstrated the similarity percentage of all isolates were 99\% (Table 2) to well several known LAB species (type strains). Furthermore, the phylogenetic analysis of 1000 bootstraps showed that fourteen isolates are clustered in four different clades (Figure 1), including clade of Lactococcus lactis (9 isolates), Lactococcus garviae (1 isolate), Enterococcus (1 isolate), and Weisella (3 isolates) with the confident level (>500 bootstraps). In general, isolates having closest relationship of $16 \mathrm{~S}$ rRNA gene with Lactococcus lactis were frequently found in the collected fruits of Tambrauw forest (64\%). Another LAB isolate of genus Lactococcus was identified as Lactococcus garvieae (Table 2). The obtained nucleotide sequences were deposited in GenBank (ncbi.nlm.nih.gov) and assigned the following accession numbers: MK759906, MK759948, MK760562, MK760566, MK760928, MK761005, MK761013, MK761065, MK761134, MK761150, MK761192, MK761194, MK771836, and MK771857.

The profiles of the LAB in the wild fruits in Tambrauw forest were previously not clearly known. Previous study reported $\mathrm{LAB}$ in domesticated fruit such as new species of Lactobacillus musae sp. nov. from bananas (Chen et al. 2017). The existence of Lactobacillus spp. and Weisella spp. dominated the LAB in bananas from Taiwan have been also reported (Yu et al. 2017). W. cibaria was reported as the most commonly found species in mulberry of several plantation areas, as well as Lactobacillus plantarum and Lactococcus lactis subsp. lactis (Chen et al. 2010). In this study we did not find the presence of Lactobacillus in fruits, however, several strains of Lactococcus have been observed. A study conducted on 
coffee plantations in Taiwan demonstrated a tendency for different LAB distributions depending on the high level of the area. Species of Lactococcus lactis subsp. lactis was commonly found in the coffee cherry on farms at the altitude of $1,200 \mathrm{~m}$ above sea level, while the heterofermentative Leuconostoc spp. and Weissella spp. frequently found in the lower areas of $800 \mathrm{~m}$ above sea level (Leong et al. 2014). In this study, however, we did not specifically study the distribution of LAB in fruit at different altitudes due to fruit plants distributed unevenly in the Tambrauw forest area. However, the presence of several LAB genera identified in this study including Lactococcus (2 species), Weissella (2 species), and Enterococcus (1 species) harboring in 10 fruit plants of Tambrauw forest area was the record of biological resources in West Papua, Indonesia.

We only found the isolates belonging to genus of Weissella with high relationship to $W$. oryzae and $W$. confusa. No species W. cibaria was observed in all samples of this study. The presence of $W$. confusa and W. cibaria isolated from fruits were reported previously. By nested PCR analysis, the occurrence of $W$. confusa and W. cibaria was quite frequently found with a level of approximately 13-18\% (Emerenini et al. 2013). W. oryzae was originally reported not from fruit, but from fermented Japanese (Oryza sativa L. subsp. japonica) (Tohno et al. 2013). The phenomenon of the discovery of this species in fruits showed considerable distribution in various plant habitats. In further studies, W. oryzae strain of $\mathrm{SG}_{2} 5^{\mathrm{T}}$ has been successfully characterized and was known to have about $2.13 \mathrm{Mbp}$ of the genome. From the comparison with other LABs, it was known that the pathway of arginine deiminase (ADI) is similar to that found in the genus Lactococcus rather than other genera of Weissella. In addition, this species has a pathway of agmatine deiminase $(\mathrm{AgDI})$ that is not found in other members of the Weissella genus indicating the possibility of horizontal gene transfer (Tanizawa et al. 2014). The phenomenon of horizontal gene transfer may be related to the adaptability of a particular microbial strain.

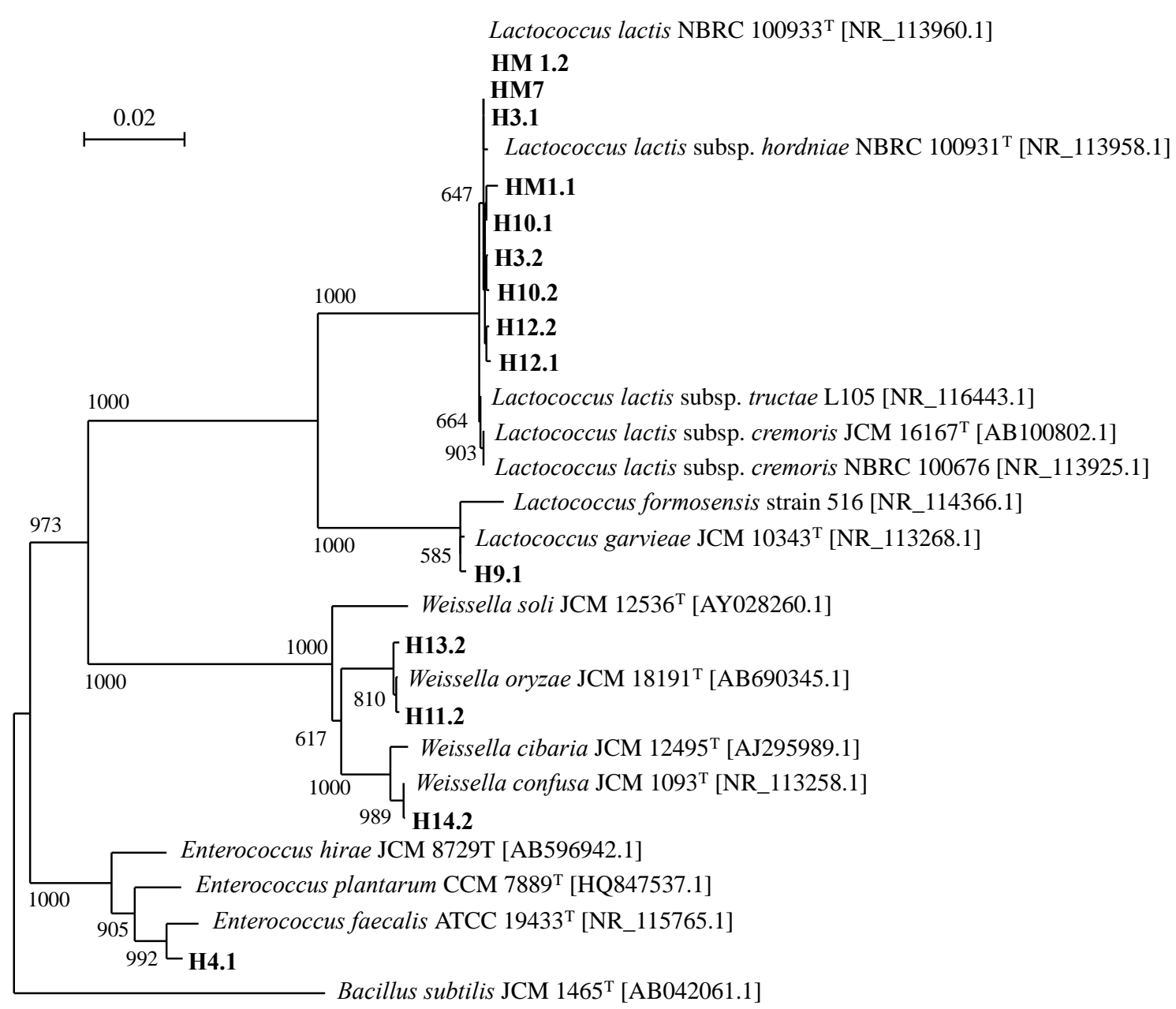

Figure 1. Phylogenetic tree of $16 \mathrm{~S}$ rRNA sequences of isolates obtained from fruits collected in Tambrauw forest, West Papua. Phylogenetic tree was constructed based on 16S rRNA gene sequencing by neighbor-joining method. Distances were estimated according to the Kimura two-parameter model with bootstrap percentages after 1000 simulations. The bar represents a $2 \%$ estimated sequence divergence. Bacillus subtilis JCM $1465^{\mathrm{T}}$ was used as an outgroup. 
Table 1. The list of wild plants collected from Tambrauw forest, West Papua, Indonesia

\begin{tabular}{|c|c|c|c|}
\hline \multicolumn{2}{|c|}{ Identified plant } & \multicolumn{2}{|c|}{ Sampling site } \\
\hline Species & Family & Location name & Coordinate \\
\hline Donax canniformis (G.Forst.) K.Schum & Marantaceae & Fef & $00^{\circ} 48^{\prime} 50.2^{\prime \prime S} 132^{\circ} 25^{\prime} 84.44^{\prime \prime E}$ \\
\hline Dysoxylum parasiticum (Osbeck) Kostern & Meliaceae & Fef & $00^{\circ} 48^{\prime} 50.2^{\prime \prime} \mathrm{S} 132^{\circ} 25^{\prime} 84.44^{\prime \prime} \mathrm{E}$ \\
\hline Tabernaemontana aurantiaca Gaudich & Apocynaceae & Fef & $00^{\circ} 48^{\prime} 50.2^{\prime \prime S} 132^{\circ} 25^{\prime} 84.44 " \mathrm{E}$ \\
\hline Tetrastigma papillosum Planch & Vitaceae & Fef & $00^{\circ} 48^{\prime} 50.2^{\prime \prime} \mathrm{S} 132^{\circ} 25^{\prime} 84.44^{\prime \prime} \mathrm{E}$ \\
\hline Ficus arfakensis King & Moraceae & Fef & $00^{\circ} 47^{\prime} 46.6^{\prime \prime S} 132^{\circ} 26^{\prime 2} 23.5^{\prime \prime E}$ \\
\hline Pinanga sp. & Arecaceae & Fef & $00^{\circ} 47^{\prime} 46.6^{\prime \prime S} 132^{\circ} 26^{\prime} 23.5^{\prime \prime E}$ \\
\hline Lasianthus sp. & Rubiaceae & Ibbe & $00^{\circ} 48^{\prime} 09.8^{\prime \prime S} 132^{\circ} 25^{\prime} 15.5^{\prime \prime E}$ \\
\hline Dracaena angustifolia (Medik.) Roxb & Dracaenaceae & Ibbe & $00^{\circ} 48^{\prime} 09.8^{\prime \prime S} 132^{\circ} 25^{\prime} 15.5^{\prime \prime E}$ \\
\hline Syzygium sp. & Myrtaceae & Ibbe & $00^{\circ} 48^{\prime} 09.8^{\prime \prime S} 132^{\circ} 25^{\prime} 15.5^{\prime \prime E}$ \\
\hline Myristica subalulata Miq & Myristicaceae & Ibbe & $00^{\circ} 48^{\prime} 09.8^{\prime \prime S} 132^{\circ} 25^{\prime} 15.5^{\prime \prime E}$ \\
\hline Helicia moluccana $(\mathrm{R}, \mathrm{Br})$ Blume & Proteaceae & Ibbe & $00^{\circ} 48^{\prime} 09.8^{\prime \prime S} 132^{\circ} 25^{\prime} 15.5^{\prime \prime E}$ \\
\hline Galearia celebica Koord & Pandanaceae & Ibbe & $00^{\circ} 48^{\prime} 09.8^{\prime \prime S} 132^{\circ} 25^{\prime} 15.5^{\prime \prime} \mathrm{E}$ \\
\hline Cordyline sp. & Asparagaceae & Bamus & $00^{\circ} 45^{\prime} 44.5^{\prime \prime} \mathrm{S} 132^{\circ} 15^{\prime} 50.4^{\prime \prime E}$ \\
\hline Capparis sp. & Cappareceae & Bamus & $00^{\circ} 45^{\prime} 44.5^{\prime \prime} \mathrm{S} 132^{\circ} 15^{\prime} 50.4^{\prime \prime} \mathrm{E}$ \\
\hline
\end{tabular}

Table 2. BLAST results of 16S rRNA gene of isolates obtained from fruits collected in Tambrauw forest, West Papua, Indonesia

\begin{tabular}{|c|c|c|c|}
\hline Source of fruit & Isolate & Closest relationship [Accession No] & Similarity $(\%)$ \\
\hline$\overline{\text { Capparis sp. }}$ & H14.2 & Weissella confusa JCM 1093 ${ }^{\mathrm{T}}[\mathrm{NR} 113258.1]$ & 99.9 \\
\hline Cordyline sp. & $\mathrm{H} 13.2$ & Weissella oryzae strain SG25 $5^{\mathrm{T}}[\mathrm{NR} 114312.1]$ & 99.6 \\
\hline \multirow[t]{2}{*}{ Donax canniformis (G.Forst.) K.Schum } & HM1.1 & Lactococcus lactis NBRC $100933^{\mathrm{T}}[\mathrm{NR} 113960.1]$ & 99.7 \\
\hline & HM1.2 & Lactococcus lactis subsp. hordniae NBRC $100931^{\mathrm{T}}[\mathrm{NR} 113958.1]$ & 99.9 \\
\hline \multirow{2}{*}{ Galearia celebica Koord } & $\mathrm{H} 12.1$ & Lactococcus lactis NBRC $100933^{\mathrm{T}}[\mathrm{NR} 113960.1]$ & 99.8 \\
\hline & $\mathrm{H} 12.2$ & Lactococcus lactis NBRC $100933^{\mathrm{T}}$ [NR113960.1] & 99.8 \\
\hline Helicia moluccana (R. Br.) Blume & $\mathrm{H} 11.2$ & Weissella oryzae SG25 ${ }^{\mathrm{T}}[\mathrm{NR} 114312.1]$ & 99.8 \\
\hline Lasianthus sp. & HM7 & Lactococcus lactis subsp. hordniae NBRC $100931^{\mathrm{T}}$ [NR113958.1] & 99.9 \\
\hline \multirow[t]{2}{*}{ Myristica subalulata Miq } & H10.1 & Lactococcus lactis NBRC $100933^{\mathrm{T}}[\mathrm{NR} 113960.1]$ & 99.9 \\
\hline & H10.2 & Lactococcus lactis NBRC $100933^{\mathrm{T}}[\mathrm{NR} 113960.1]$ & 99.8 \\
\hline Syzygium sp. & H9.1 & Lactococcus garvieae JCM $10343^{\mathrm{T}}[\mathrm{NR} 113268.1]$ & 99.8 \\
\hline \multirow[t]{2}{*}{ Tabernaemontana aurantiaca Gaudich } & $\mathrm{H} 3.1$ & Lactococcus lactis subsp. hordniae NBRC $100931^{\mathrm{T}}$ [NR113958.1] & 99.9 \\
\hline & $\mathrm{H} 3.2$ & Lactococcus lactis subsp. hordniae NBRC $100931^{\mathrm{T}}$ [NR113958.1] & 99.8 \\
\hline Tetrasigma papillosum Planch & $\mathrm{H} 4.1$ & Enterococcus faecalis ATCC $19433^{\mathrm{T}}[\mathrm{NR} 115765.1]$ & 99.1 \\
\hline
\end{tabular}

Although the existence of microbes on fruits was caused by various factors, such as through air, water, dust of earth, spread by animals, or already exist in the plant seed (Barth et al. 2009). The chemical components of the fruit could the defining factor of the $\mathrm{LAB}$ niche. Lactic acid bacteria whose preference is fructose (fructophilic $\mathrm{LAB}$ ) were commonly found in fruits that contain a great deal of fructose. Fructophilic LAB was found in the digestive tract of insects as well (Endo 2012). Based on16S RNA gene, the LAB isolates were mostly Lactococcus lactis type from fruits spread in various locations (Table 1). However, there was only one isolate, L. lactis (HM1.1), showed antimicrobial activity. Based on the phylogenetic relationship between $L$. lactis species, the HM1.1 isolate showed a distinct difference (Figure 1). Whereas $W$. confusa was reported to be beneficial as a probiotic, the same species could also infect animals and humans. As well, Lac. garvieae was also documented for its pathogenicity (Ferrario et al. 2013; Morita et al. 2011).
Thus, precaution must be taken prior application or utilization (Fairfax et al. 2014).

\section{Antimicrobial activity}

All isolated lactic acid bacteria demonstrated the antimicrobial activity against three indicator strains, E. coli, $S$. aureus, and M. smegmatis. However, only two strains are known as HM.1.1 (Lac. lactis) and HM 14.2 (W. confusa) strongly inhibited the growth of $S$. aureus and $M$. smegmatis. Strain HM1.1 showed a $4.5 \mathrm{~mm}$ inhibition zone on $M$. smegmatis, while H14.2 had a $2.0 \mathrm{~mm}$ inhibition zone. Isolate HM1.1 had a $2.0 \mathrm{~mm}$ inhibition zone on $S$. aureus and $\mathrm{H} 14.2$ has a $1.5 \mathrm{~mm}$ inhibition zone. Further testing was performed on both cultures. As result of MIC test, supernatant of H14.2 (W. confusa) and HM1.1 (Lac. lactis) inhibited the growth of three microbial targets; $M$. smegmatis was more sensitive than $S$. aureus and $E$. coli (Table 3). However, the activity was still lower than the antimicrobial activity of strain from commercial probiotics products. 
Table 3. Antimicrobial activity of H14.2 and HM1.1 supernatants on Staphylococcus aureus, Escherichia coli, and Mycobacterium smegmatis

\begin{tabular}{|c|c|c|c|c|c|c|}
\hline \multirow{3}{*}{ LAB supernatant } & \multicolumn{6}{|c|}{ MIC of supernatant on target microbes $(\%, v / v)$} \\
\hline & \multicolumn{2}{|c|}{ S. aureus } & \multicolumn{2}{|c|}{ E. coli } & \multicolumn{2}{|c|}{ M. smegmatis } \\
\hline & Unheated & Heated & Unheated & Heated & Unheated & Heated \\
\hline Strain from commercial probiotic product (Lb. casei) & 10 & $20 *$ & 20 & 20 & 5 & 5 \\
\hline H14.2 (W. confusa) & 40 & 40 & 40 & 40 & 20 & $40 *$ \\
\hline HM1.1 (Lac. lactis) & 40 & 40 & 40 & 40 & 20 & $40^{*}$ \\
\hline
\end{tabular}

Note: *: activity was decreased after heating at $80^{\circ} \mathrm{C}$ for $15 \mathrm{~min}$ compared to MIC of supernatant before treatment

The application of high temperatures resulted in the decreasing of antimicrobial activity of H14.2 (W. confusa) and HM1.1 (Lac. lactis) on pathogenic model $M$. smegmatic, indicated by elevated MIC values of heated supernatant compared to non-heated samples (Table 3). The activity of the commercial LAB supernatant did not show any changes on M. smegmatis, while the activity on $S$. aureus was reduced. We suggest three possibilities that could explain this different activity of heated supernatant against targeted microorganisms. First, supernatant may contain different bacteriocins so that there will be other bacteriocins that are still active against certain bacteria. Second, bacteriocin might not be completely denatured so that there will be peptide residues that are still active against certain bacteria. Third, supernatant may contain unknown substances whose antimicrobial activity against certain bacteria is not affected by high temperature. However, these suggestions need to be further studied.

Antimicrobial activity is one of LAB probiotics properties. The antimicrobial properties of LAB are affected by hydrogen peroxide, bacteriocin, organic acids formed; such as lactic acid and acetic acid, and antifungal peptides (Reis et al. 2012). To the best of our knowledge, there is limited or no report on LAB isolated or identified from genus of the studied fruits except Capparis sp. In natural fermentation of caper berry fruit Lactobacillus spp., Pediococcus spp., Enterococcus spp. were identified (Pulido et al. 2005). Although originally probiotics found in humans, recently it can also be derived from wild fruits and vegetables (Bae et al. 2006; Benavides et al. 2016; Chen et al. 2010). The activity of the supernatant of both LAB $W$. confusa HM14.2 and Lac. lactis HM1.1 against $M$. smegmatis decreased after heating at high temperature (Table 3). It indicated the possibility of H14.2 or HM1.1 being anti-M. smegmatic due to the content of both BAL that was damaged by high temperature $\left(80^{\circ} \mathrm{C}\right)$ for 15 minutes. Peptide is one of the LAB content that plays important role in antimicrobial activity (Cotter et al. 2013; Grosu-Tudor et al. 2014). Several purified bacteriocin peptides were reported previously from Lac. lactis (Goyal et al., 2018) and W. confusa (Sartono et al. 2019). Peptides usually could not withstand high temperatures, although some are resistant to high temperatures (Maria and Janakiraman 2012). Some bacteriocins are known to kill $M$. tuberculosis with the membrane as a target (Sosunov et al. 2007).

In conclusion, total of fourteen LABs has been successfully isolated from the eight fruits of wild plants in
Tambrauw forest area, West Papua. Those LAB strains had closest relationship to species Lactococcus lactis, Lactococcus garvieae, Weissella confusa, Weissella oryzae, and Enterococcus faecalis. The supernatant of Lac. lactis HM 1.1 from Donax canniformis and W. confusa H14.2 from Capparis sp. showed higher the highest inhibition on E. coli, S. aureus, and M. smegmatis. The data showed that wild fruits from Tambrauw forest harbor beneficial bacteria that could be important for health of animals and humans as well.

\section{ACKNOWLEDGEMENTS}

This study was supported financially by DIPA from Research Center for Biology, LIPI, Bogor, Indonesia. Authors thank Mulyadi for samples collection in Tambrauw forest, West Papua, Indonesia and Deni Sahroni for plants identification

\section{REFERENCES}

Albertti LAG, Souza-Filho AF, Fonseca-Júnior AA, Freitas ME, de Oliveira-Pellegrin A, Zimmermann NP, Tomás WM, Péres IAHFS, Fontana I, Osório ALAR. 2014. Mycobacteria species in wild mammals of the Pantanal of central South America. Eur J Wildl Res 61: $163-166$.

Ali AA. 2010. Beneficial role of lactic acid bacteria in food preservation and human health: a review. Res J Microbiol 5: 1213-1221.

Bae S, Fleet GH, Heard GM. 2006. Lactic acid bacteria associated with wine grapes from several Australian vineyards. J Appl Microbiol 100: 712-727.

Barth M, Hankinson TR, Zhuang H, Breidt F. 2009. Microbiological spoilage of foods and beverages. In: Sperbe WH, Doyle MP (eds) Compendium of the microbiological spoilage of foods and beverages. Springer Science+Business Media, New York

Benavides AB, Ulcuango M, Yépez L, Tenea GN. 2016. Assessment of the in vitro bioactive properties of lactic acid bacteria isolated from native ecological niches of Ecuador. Rev Argent Microbiol 48: 236244.

Bungenstock L, Abdulmawjood A, Reich F. 2020. Evaluation of antibacterial properties of lactic acid bacteria from traditionally and industrially produced fermented sausages from Germany. PLoS One 15: e0230345. DOI: 10.1371/journal.pone.0230345.

Chen Y, Wang L, Liao Y, Lan Y, Chang C, Chang Y, Wu H, Lo H, Otoguro M, Yanagida F. 2017. Lactobacillus musae sp. nov., a novel lactic acid bacterium isolated from banana fruits. Intl J Syst Evol Microbiol 67: 5144-5149.

Chen Y, Wu H, Yanagida F. 2010. Isolation and characterization of lactic acid bacteria from ripe mulberries in Taiwan. Braz $\mathbf{J}$ Microbiol 41: 916-921. 
Choi JI, Yoon KH, Subbammal Kalichamy S, Yoon SS, Lee JIl. 2016. A natural odor attraction between lactic acid bacteria and the nematode Caenorhabditis elegans. ISME J 10: 558-567.

Cotter PD, Ross RP, Hill C. 2013. Bacteriocins - a viable alternative to antibiotics? Nat Rev Microbiol 11: 95-105.

de Godoy I, Moraes DF da SD, Pitchenin LC, Rosa JMA, Kagueyama FC, da Silva A de J, Dutra V, Nakazato L. 2016. Antimicrobial susceptibility profiles of Staphylococcus spp. from domestic and wild animals. Ciência Rural 46: 2148-2151.

El Baz A, Shetaia Y. 2005. Evaluation of different assays for the activity of yeast killer toxin. Intl J Agric Biol 7: 1003-1006.

Emerenini EC, Afolabi OR, Okolie PI, Akintokun AK. 2013. Isolation and molecular characterization of lactic acid bacteria isolated from fresh fruits and vegetables using nested PCR analysis. Br Microbiol Res J 3: $368-377$.

Endo A. 2012. Fructophilic lactic acid bacteria inhabit fructose-rich niches in nature. Microb Ecol Heal Dis 23: 6-9. DOI 10.3402/mehd.v23i0.18563.

Fairfax MR, Lephart PR, Salimnia H. 2014. Weissella confusa: problems with identification of an opportunistic pathogen that has been found in fermented foods and proposed as a probiotic. Front Microbiol 5: 254 DOI: 10.3389/fmicb.2014.00254

Ferrario C, Ricci G, Milani C, Lugli GA, Ventura M, Eraclio G, Borgo F, Fortina MG. 2013. Lactococcus garvieae: where is it from? A firs approach to explore the evolutionary history of this emerging pathogen. PLoS One 8: e84796. DOI: 10.1371/journal.pone.0230345.

Gowri RS, Meenambigai P, Prabhavathi P, Raja Rajeswari P, Yesudoss LA. 2016. Probiotics and its effects on human health - A review. Intl J Curr Microbiol Appl Sci 5: 384-392.

Goyal C, Malik RK, Pradhan D. 2018. Purification and characterization of a broad spectrum bacteriocin produced by a selected Lactococcus lactis strain 63 isolated from Indian dairy products. J Food Sci Technol 55: 3683-3692.

Grosu-Tudor SS, Stancu MM, Pelinescu D, Zamfir M. 2014 Characterization of some bacteriocins produced by lactic acid bacteria isolated from fermented foods. World J Microbiol Biotechnol 30: 2459-2469

Hwanhlem N, Chobert JM, H-Kittikun A. 2014. Bacteriocin-producing lactic acid bacteria isolated from mangrove forests in southern Thailand as potential bio-control agents in food: Isolation, screening and optimization. Food Control 41: 202-211.

Iovine R de O, Dejuste C, Miranda F, Filoni C, Bueno MG, Carvalho VM de. 2015. Isolation of Escherichia coli and Salmonella spp. from freeranging wild animals. Braz J Microbiol 46: 1257-1263.

Kamaladevi A, Ganguli A, Balamurugan K. 2016. Lactobacillus case stimulates phase-II detoxification system and rescues malathioninduced physiological impairments in Caenorhabditis elegans. Comp Biochem Physiol Part - C Toxicol Pharmacol 179: 19-28.

Kamaladevi A, Ganguli A, Kumar M, Balamurugan K. 2013 Lactobacillus casei protects malathion induced oxidative stress and macromolecular changes in Caenorhabditis elegans. Pestic Biochem Physiol 105: 213-223.

Karyawati AT, Nuraida L, Lestari Y, Meryandini A. 2018 Characterization of abundance and diversity of lactic acid bacteria from Apis dorsata hives and flowers in East Nusa Tenggara Indonesia. Biodiversitas 19 (3): 899-905.

Lane DJ, Pace B, Olsen GJ, Stahlt DA, Sogint ML, Pace NR. 1985. Rapid determination of $16 \mathrm{~S}$ ribosomal RNA sequences for phylogenetic analyses. PNAS 82: 6955-6959.

Leong K, Chen Y, Pan S, Chen J, Wu H, Chang YC, Yanagida F. 2014 Diversity of lactic acid bacteria associated with fresh coffee cherries in Taiwan. Curr Microbiol 68: 440-447.

Makarova K, Slesarev A, Wolf Y, Sorokin A, Mirkin B, Koonin E, Pavlov A, Pavlova N, Karamychev V, Polouchine N, Shakhova V, Grigoriev I, Lou Y, Rohksar D, Lucas S, Huang K, Goodstein DM, Hawkins T, Plengvidhya V, Welker D, Hughes J, Goh Y, Benson A, Baldwin K, Lee J-H, Diaz-Muniz I, Dosti B, Smeianov V, Wechter W, Barabote R, Lorca G, Altermann E, Barrangou R, Ganesan B, Xie Y, Rawsthorne H, Tamir D, Parker C, Breidt F, Broadbent J, Hutkins R, O'Sullivan D, Steele J, Unlu G, Saier M, Klaenhammer T, Richardson P, Kozyavkin S, Weimer B, Mills D. 2006. Comparative genomics of the lactic acid bacteria. Proc Natl Acad Sci USA 103: 15611-15616.
Mangunwardoyo W, Salamah A, Sukara E, Sulistiani, Dinoto A. 2016. Diversity and distribution of culturable lactic acid bacterial species in Indonesian Sayur Asin. Iran J Microbiol 8: 274-281.

Maria M, Janakiraman S. 2012. Detection of heat-stable bacteriocin from Lactobacillus acidophilus NCIM5426 by liquid chromatography/mass spectrometry. Indian J Sci Technol 5: 2325-2332.

Montet D, Ray RC, Zakhia-Rozis N. 2014. Lactic acid fermentation of vegetables and fruits. In: Ray RC, Montet D (eds) Microorganisms and fermentation of traditional foods. CRC Press, Boca Raton, FL.

Moodley S, Koorbanally NA, Moodley T, Ramjugernath D, Pillay M. 2014. The 3-(4,5-dimethylthiazol-2-yl)-2,5-diphenyl tetrazolium bromide (MTT) assay is a rapid, cheap, screening test for the in vitro anti-tuberculous activity of chalcones. J Microbiol Methods 104: 7278

Morita H, Toh H, Oshima K, Yoshizaki M, Kawanishi M, Nakaya K, Suzuki T, Miyauchi E, Ishii Y, Tanabe S, Murakami M, Hattori M. 2011. Complete genome sequence and comparative analysis of the fish pathogen Lactococcus garvieae. PLoS One 6: e23184. DOI: 10.1371/journal.pone.0023184.

Noonpakdee W, Santivarangkna C, Jumriangrit P, Sonomoto K, Panyim S. 2002. Isolation of nisin-producing Lactococcus lactis WNC 20 strain from nham, a traditional Thai fermented sausage. Intl J Food Microbiol 81: 137-145.

Pulido RP, Ben Omar N, Abriouel H, López RL, Cañamero MM, Gálvez A. 2005. Microbiological study of lactic acid fermentation of caper berries by molecular and culture-dependent methods. Appl Environ Microbiol 71: 7872-7879.

Reis JA, Paula AT, Casarotti SN, Penna ALB. 2012. Lactic acid bacteria antimicrobial compounds: characteristics and applications. Food Eng Rev 4: 124-140.

Robiansyah I. 2018. Diversity and biomass of tree species in Tambrauw, West Papua, Indonesia. Biodiversitas 19: 377-386.

Saito H, Miura K-I. 1963. Preparation of transforming deoxyribonucleic acid by phenol treatment. Biochim Biophys Acta 72: 619-629.

Saitou N, Nei M. 1987. The neighbor-joining method: a new method for reconstructing phylogenetic trees. Mol Biol Evol 4: 406-425.

Sangari FJ, Goodman J, Petrofsky M, Kolonoski P, Bermudez LE. 2001. Mycobacterium avium invades the intestinal mucosa primarily by interacting with enterocytes. Infect Immun 69: 1515-1520.

Sartono G, Rizqiyah I, Asmarinah, Heng NCK, Malik A. 2019. Three bacteriocin peptides from a lactic acid bacterium Weissella confusa MBF8-1 with spermicidal activity. Curr Pharm Biotechnol 20: 766771.

Sosunov V, Mischenko V, Eruslanov B, Svetoch E, Shakina Y, Stern N, Majorov K, Sorokoumova G, Selishcheva A, Apt A. 2007. Antimycobacterial activity of bacteriocins and their complexes with liposomes. J Antimicrob Chemother 59: 919-925.

Sulistiani, Abinawanto, Sukara E, Salamah A, Dinoto A, Mangunwardoyo W. 2014. Identification of lactic acid bacteria in sayur asin from Central Java (Indonesia) based on 16S rDNA sequence. Intl Food Res J 21: 527-532.

Swain MR, Anandharaj M, Ray RC, Rani RP. 2014. Fermented fruits and vegetables of Asia: a potential source of probiotics. Biotechnol Res Intl 2014: 250424. DOI: 10.1155/2014/250424.

Tanizawa Y, Fujisawa T, Mochizuki T, Kaminuma E, Suzuki Y, Nakamura Y, Tohno M. 2014. Draft genome sequence of Weissella oryzae SG25T, isolated from fermented rice grains. Genome Announc 2 (4): e00667-14. DOI: 10.1128/genomeA.00667-14.

Thompson JD, Gibson TJ, Plewniak F, Jeanmougin F, Higgins DG. 1997. The CLUSTAL _ $\mathrm{X}$ windows interface: flexible strategies for multiple sequence alignment aided by quality analysis tools. Nucleic Acid Res 25: 4876-4882.

Tohno M, Kitahara M, Inoue H, Uegaki R, Irisawa T, Ohkuma M, Tajima K. 2013. Weissella oryzae sp. nov., isolated from fermented rice grains. Intl J Syst Evol Microbiol 63: 1417-1420.

Tsuchida S, Takahashi S, Nguema MPP, Fujita S, Kitahara M, Yamagiwa J, Ngomanda A, Ohkuma M, Ushida K. 2014. Bifidobacterium moukalabense sp. nov., isolated from the faeces of wild west lowland gorilla (Gorilla gorilla gorilla). Intl J Syst Evol Microbiol 64: 449455.

Wanger A. 2007. Disk diffusion test and gradient methodologies. In: Schwalbe R, Steele-Moore L, Goodwin AC (eds) Antimicrobial Susceptibility Testing Protocols. CRC Press, New York.

Yu C, Hui L, Yanagida F. 2017. Diversity of lactic acid bacteria associated with banana fruits in Taiwan. Curr Microbiol 74: 484-490. 